\title{
Physicochemical and Sensory Evaluation of Tomato Varieties (Lycopersicum Esculentum Mill) From the Haut-Sassandra Region (Daloa) Côte d'Ivoire
}

\author{
Ekissi Alice Christine ${ }^{1 *}$, Kouame Kan Benjamin ${ }^{1}$, Beugre Grah Avit Maxwell ${ }^{1}$, Séraphin Kati-Coulibaly ${ }^{2}$ \\ ${ }^{1}$ Agro-valorization Laboratory, Faculty of Agroforestry, University Jean Lorougnon Guede of Daloa, Daloa, Cote d'Ivoire \\ ${ }^{2}$ Laboratory of Nutrition and Pharmacology, of Biosciences, University Felix Houphouet Boigny of Cocody-Abidjan, Abidjan, Cote
} d'Ivoire

\section{Article History}

Received: 28.01.2021

Accepted: 16.03 .2021

Published: 30.03 .2021

Journal homepage: https://www.easpublisher.com

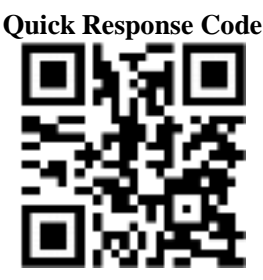

Abstract: The tomato (Lycopersicum esculentum Mill) is the most consumed vegetable fruit in the world. It contributes to the proper functioning of the body. It is a good source of bioactive substances against cardiovascular and metabolic diseases (diabetes) and cancers. The objective of this study is to determine the physicochemical and organoleptic characteristics of three varieties of tomato. The samples were taken from producers in the town of Daloa. The physicochemical parameters (water, ash, vitamin $\mathrm{C}$, degree, brix, $\mathrm{pH}$ and titratable acidity) were determined by standardized methods, an organoleptic analysis (hedonic test and sensory profile) was carried out. The results showed that the contents of water (91.36 and 94.52\%), ash (10.63\%-13.28\%) and vitamin C (150.28\% -156.15\%) were high, but the contents in degree Brix $\left(4\right.$ to $\left.7.93^{\circ} \mathrm{Brix}\right)$, the $\mathrm{pH}(4.06 \%-4.36 \%)$, in titratable acidity ( 5.12 to $9.33 \pm 1.53$ meq.g / $100 \mathrm{~g}$ ) are weak. For sensory analysis, all tomatoes are accepted by tasters; however variety A1 is less than those of Kilélé and Cobra 26. The sensory profile shows a difference between the three varieties. Tomatoes are good sources of nutrients, especially vitamin C. It would be interesting to include them daily in our diets. Keywords: Lycopersicum esculentum, tomato, organoleptic, hedonic, sensory profile, fruitvegetable, Côte d'Ivoire.

Copyright (C) 2021 The Author(s): This is an open-access article distributed under the terms of the Creative Commons Attribution 4.0 International License (CC BY-NC 4.0) which permits unrestricted use, distribution, and reproduction in any medium for non-commercial use provided the original author and source are credited.

\section{INTRODUCTION}

Diet is now seen as one of the factors of public health, and fruits and vegetables are particularly recommended. Three arguments underpin the health benefits of fruits and vegetables [1]. These fruits and vegetables make an important contribution to the micronutrients necessary for the proper functioning of the body. They provide a protective effect against the major chronic pathologies such as cardiovascular, neurodegenerative and metabolic diseases (diabetes) and cancers. Finally, they are low in calories, but rich in minerals [1, 2]. Vegetables and fruits are of great importance in the human diet, providing an important source of bioactive substances. Among the latter, the Solanum Lycopersicum tomato represents them apart from its commercial and food properties. The tomato, Lycopersicum esculentum Miller, is an annual plant in the Solanaceae family. In addition, tomato cultivation plays an important socio-economic role within populations because it represents an important source of income [3, 4].

This popular vegetable is known as an important source of important nutrients including lycopene, $\beta$-carotene, flavonoids and vitamin $\mathrm{C}$ as well as hydroxycinnamic acid derivatives [5]. Consumed in several forms (raw, cooked, or processed), the tomato is considered a dietetic food. It is an important source of healthy antioxidants and vitamins (ascorbic acid and $\alpha$ tocopherol) involved in the process of cell detoxification and helps prevent many cancers [2]. In Côte d'Ivoire, the great availability of fertile land and hydrological resources associated with a favorable climate and good vegetation is an asset for the production of a large number of tomato varieties. Despite this, annual tomato production fluctuates between 22,000 and 35,000 tons with a period of abundance from June to September [6]. This production is only sufficient to cover one third of the needs of the Ivorian population [4]. Notwithstanding, the tomato more and more solicited for its multiple uses, however, is found to be in limited quantity to cover the needs of the populations.

This makes tomato an expensive product during lean periods. However, despite the undeniable interest of the tomato in the Ivorian food sector, very little work has been devoted to the study of the physicochemical and organoleptic characterization of the different varieties of tomato. It is therefore imperative to know the current physicochemical and organoleptic characteristics of the different varieties of tomato produced in each agro-ecological region. The 
results of the physicochemical and organoleptic characterization could provide a better understanding of the nutritional value of tomato varieties produced in the locality of Daloa. These data could help encourage farmers to produce tomatoes in quantity and quality so that they are available in quantity to local populations. It is with this in mind that the present study was initiated.

The objective of this work is to evaluate the physicochemical and organoleptic characteristics of the varieties of tomato produced in order to establish the differences between the varieties of tomato on the one hand and on the other hand to improve the quality of this product in the Haut region. Haut-Sassandra (Côte d'Ivoire).

\section{MATERIAL AND METHODS MATERIAL}

\subsubsection{Biological material}

The biochemically analyzed biological material consists of three varieties of tomatoes. These tomato varieties are most available during the dry season and were collected from growers in Daloa town. These are two hybrid varieties (Kilélé and Cobra 26) and the old variety (A1) (Figure 1).

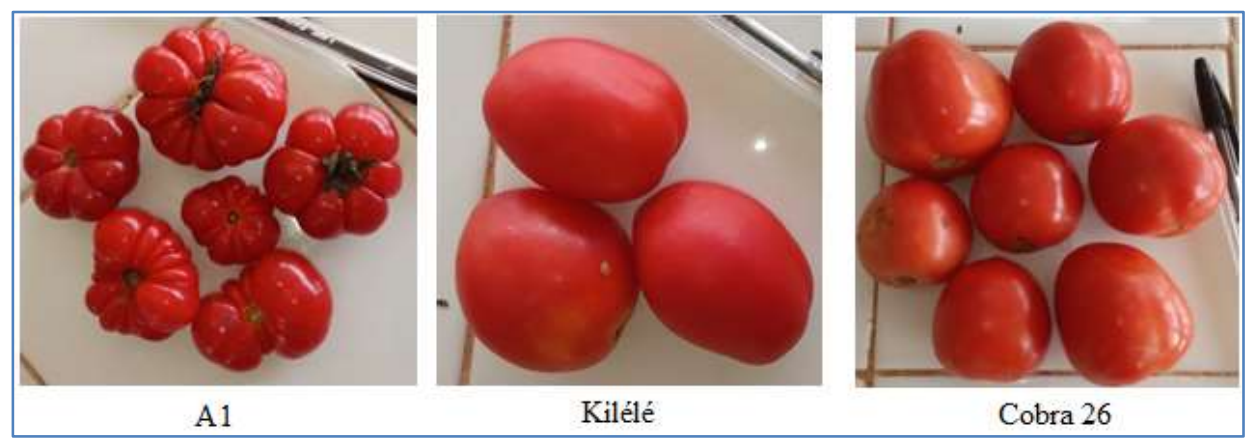

Fig-1: Photograph of three varieties of tomato

\section{METHODS}

\subsubsection{Biochemical analyzes of tomato samples}

2.2.3.1 Sampling

The samples concerned three varieties of tomato, namely the hybrid varieties (Kilélé and Cobra 26) and the old variety (A1). A number of thirty (30) samples of each variety of tomato were collected. These tomato samples were purchased at random from producers and transported in baskets to the laboratory for possible physicochemical and organoleptic analyzes.

\section{Determination of water content}

The method used is that of [7] BIPEA (1976), the principle of which is based on dehydration by oven drying of the samples until a constant mass is obtained. Five (5) grams of each tomato sample was weighed using a balance (OHAUS, model: PA2102C) in a crucible of known mass (M0). The whole (crucible + powder) of mass M1 was placed in an oven (MEMMERT 854 SCHWABACH, Germany) at $105^{\circ}$ $\mathrm{C}\left( \pm 2^{\circ} \mathrm{C}\right)$ for 24 hours. After cooling in a desiccator (GLASWERK WERTHEIM, 2 bar), the crucible is weighed again (M2). Three tests were carried out for each tomato sample. The water content was determined from the following formula:

$$
\text { Water content }(\%)=\frac{\mathbf{M}_{1}-\mathbf{M}_{2}}{\text { TP }} \times 100
$$

M1: Mass of crucible + test portion $(\mathrm{g})$

M2: Mass of the assembly after baking $(\mathrm{g})$ T P: Test portion $(\mathrm{g})$

\section{Determination of ash content}

Total ash is the residue of mineral compounds that remains after the incineration of organic substances from a sample of animal or plant origin. The method used for the determination of ash content is that of [8] AOAC (1990). Five (5) grams of each flour sample was weighed using a balance (Denver, Model ABT 320 $4 \mathrm{M}$ ) into a crucible of known mass (M0). The whole (crucible + product) is heated in an oven (VELP Scientifica, Spain) at $550^{\circ} \mathrm{C}\left( \pm 2^{\circ} \mathrm{C}\right)$ for 24 hours. After cooling in a desiccator (GLASWERK WERTHEIM, 2 bars), the crucible containing the ashes is weighed and noted (M1). The tests were carried out in triplicate. The ash content was determined from the formula: 


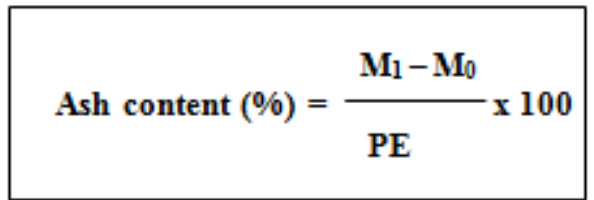

M1: Mass of crucible + ash $(\mathrm{g})$

T P: Test portion $(\mathrm{g})$

$\mathrm{M}_{0}$ : Mass of crucible $(\mathrm{g})$

\section{Determination of the refractometric dry extract}

Brix is the main technological parameter in tomato concentrates. It represents the degree of concentration of tomato juice. This parameter is subject to very strict regulation [9]. Brix is defined as the concentration of carbohydrates (mainly sucrose) in an aqueous solution having the same refractive index as the product analyzed. For analysis, a few drops of tomato juice were placed on the fixed prism of an ATAGO brand refractometer $(\mathrm{N}-1 \alpha$, Brix 0-32, JAPAN). The concentration of soluble matter measured at $20^{\circ} \mathrm{C}$ by the refractive index using the refractometer is then expressed as the percentage by mass according to a standard method (NA 5669).

\section{Determination of $\mathbf{p H}$ and titratable acidity}

The acidity and the $\mathrm{pH}$ were determined according to the method described by [10]. A quantity of $20 \mathrm{~g}$ of the various tomato fruits is diluted in $200 \mathrm{~mL}$ of distilled water forming a $10 \%(\mathrm{~m} / \mathrm{v})$ suspension. This suspension is stirred at room temperature $\left(28^{\circ} \mathrm{C}\right)$ for 30 minutes and is centrifuged at $6000 \mathrm{rpm}$ for 15 minutes. The hydrogen potential is a global expression of the acidity of a product. Thus, the $\mathrm{pH}$ of the tomatoes resulting from the various treatments is measured directly on the supernatant collected by means of a $\mathrm{pH}$ meter (Microprocessor, pHs-38w).

The purpose of titratable acidity is to approximate the total content of natural organic acids. The assay being carried out by titration with a strong base $(0.1 \mathrm{~N} \mathrm{NaOH})$ by turning a colored indicator (phenophthalein). For this purpose, a volume of $50 \mathrm{~mL}$ of the supernatant obtained previously from the tomato fruits was titrated with a sodium hydroxide solution $(0.1 \mathrm{~N} \mathrm{NaOH})$ in the presence of phenolphthalein $(1 \%$ in ethanol). The concentration of acids in food, such as acetic, citric, lactic and malic acids, is determined by titration of a test portion with sodium hydroxide until it changes to a $\mathrm{pH}$ of 8.1 [11]. The predominant acid in tomato is citric acid monohydrate which is used in the expression of results according to a standardized method (NA 691) (NF V05-101).

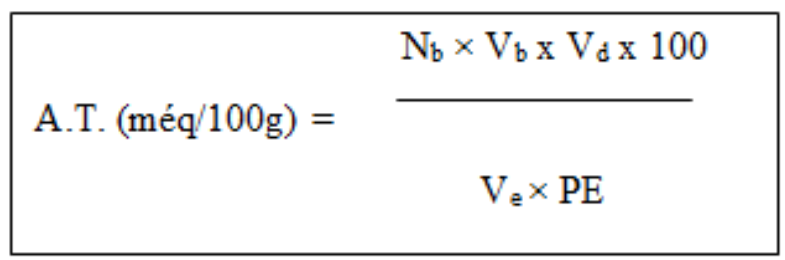

Vb: Volume of soda poured $(\mathrm{mL})$

$\mathrm{Nb}$ : Normal sodium hydroxide $(0.1 \mathrm{~N})$

$\mathrm{Vd}$ : Volume of diluent or distilled water $(\mathrm{mL})$

Ve: Test volume $(\mathrm{mL})$
PE: Test portion $(5 \mathrm{~g})$
AT: Titratable acidity

\section{Determination of vitamin $\mathbf{C}$ ( $\mathrm{L}$-acorbic acid)}

The vitamin $\mathrm{C}$ content of tomatoes from the different treatments was determined by the indirect iodometric titration method described by [12]. This method involved placing a known volume of tomato juice in the presence of a known amount of excess iodine. All of the vitamin $\mathrm{C}$ reacts with the excess diodine. The excess iodine is determined with a solution of sodium thiosulfate $\mathrm{Na} 2 \mathrm{~S} 2 \mathrm{O} 3$. Thus, a quantity of 20 grams of the tomato resulting from the treatments was crushed and dissolved in a volume of $100 \mathrm{ml}$ of distilled water. The mixture is then filtered and the juice obtained is collected in a beaker with a volume of 200 $\mathrm{mL}$. In a $20 \mathrm{~mL}$ capacity beaker, a volume of $5 \mathrm{~mL}$ of tomato juice comprising a few drops of starch starch is added to a volume of $5 \mathrm{~mL}$ of iodine of known concentration. The solution is then black from the excess iodine. The excess iodine in the solution is titrated with sodium thiosulfate solution $(\mathrm{Na} 2 \mathrm{~S} 2 \mathrm{O} 3$ at 5.10-3 mol / L) until the black color has completely disappeared.

\section{Sensory analysis of tomato samples}

Sensory analysis is an effective way to describe internal properties and give consumers preferences [13]. For the evaluation of the organoleptic quality of tomato samples, the methods used are the hedonic test and the sensory profile. The hedonic test 
and the sensory profile were carried out at the Agrovaluation Laboratory of the University Jean Lorougnon Guédé.

\section{Hedonic test}

This test was carried out using a tasting sheet prepared for this purpose. At each session, slices of tomato were cut. The tomato slices are placed on each plate. On each of the stations, the tomato slices were placed after having carefully coded them. Twelve (12) in numbers, the untrained tasters ( 80 people) who were selected, formed a panel whose age was between 20 and 45 years old. These are made up of women and men. They were recruited from the staff of Jean Lorougnon Guédé University. The tasters are called in groups of 6 people. After a briefing, they are installed in the cabin for an evaluation of the tomato slices in sequential monadic or in comparison for a period of 8 to 10 minutes. For each tomato sample, it includes: a hedonic assessment on a 9-point satisfaction scale [14]. This hedonic assessment includes a general assessment (visual, global, olfactory and an estimate of the texture and taste) of the product, free comments from consumers.

\section{Sensory profile}

The method consisted of evaluating and quantifying the appropriate descriptors (color, fluidity, clarity, aroma, flavor and astringency) according to a category scale. The intensity of the descriptors was rated on an unstructured $10 \mathrm{~cm}$ scale. From 0 for unperceived intensity to 10 for extremely intense. The panel was made up of (12) people (tasters) trained in sensory analysis, recruited on the basis of their availability and having no aversion to the product. Samples were coded (with three digits) and presented monadically to each panelist [15].

\section{STATISTICAL ANALYSIS}

The data collected was entered and processed using Microsoft Excel 2016 and Statistica 7.1 software (Statsoft Inc, Tulsa-USA Headquarters). Thus, an analysis of variance was carried out in order to appreciate the significant differences between the physicochemical parameters according to each variety of tomato analyzed. Multiple comparison tests (Tukey HSD) were conducted when the difference was found to be significant $(\mathrm{p}<0.05)$ for the purpose of separating the different samples.

\section{RESULTS AND DISCUSSION 3.1 RESULTS}

3.1.1. Comparison between the physicochemical parameters of the three varieties (A1, Cobra 26 and Kilélé)

\subsubsection{Moisture content of tomato varieties}

The average water contents of the three varieties are illustrated in figure 2. On analysis, the average water content of the tomato samples varies from $91.36 \pm 0.10 \%$ for the old variety (A1) to $94.52 \pm$ $0.20 \%$ for the improved variety (Cobra 26). The mean moisture content of the old variety (A1) differs significantly from the improved varieties (Cobra 26 and Kilélé at $\mathrm{p}<0.05$ ).

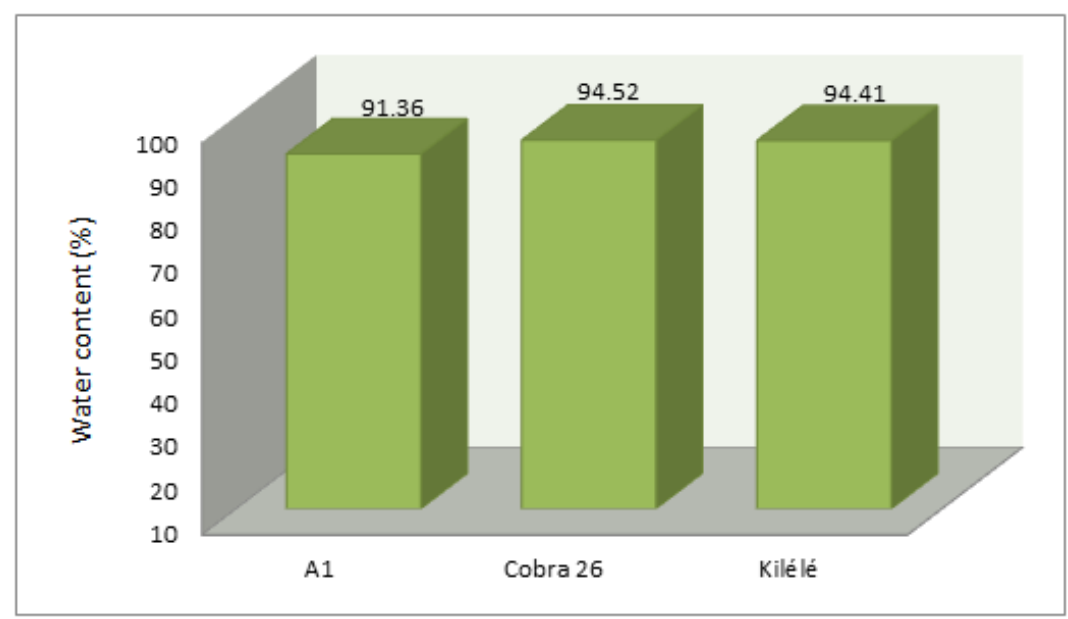

Fig-2: Water content of tomato varieties

\section{Ash content of tomato varieties}

The results of this study revealed that the average ash contents of the three varieties differed significantly at $\mathrm{p}<0.05$ (Figure 3 ). Note that the average ash contents varied from $10.63 \pm 0.30 \%$ (Cobra 26) to $13.28 \pm 0.73 \%$ (old variety $\mathrm{A} 1$ ). 


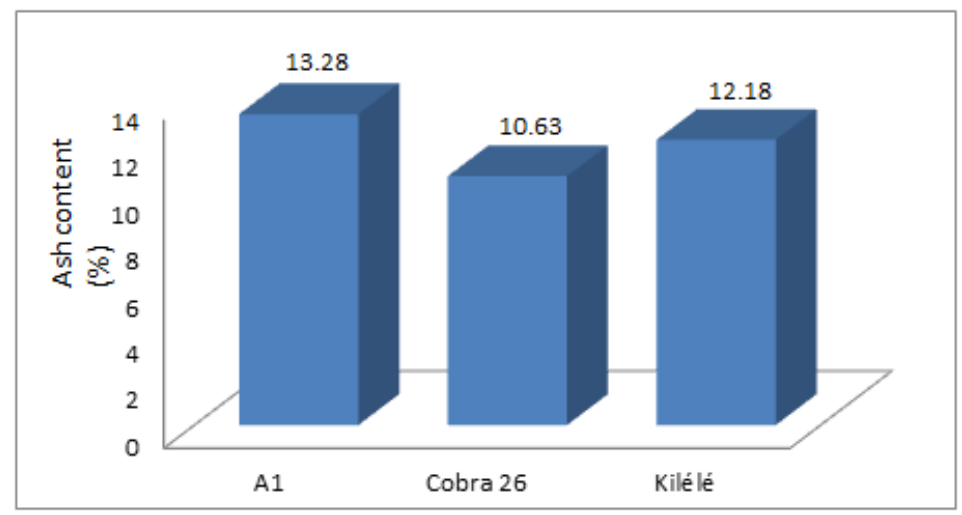

Fig-3: Ash content of tomato varieties

\section{Refractometric solids content $\left({ }^{\circ}\right.$ Brix) of tomato} varieties

The mean refractometric dry extract $\left({ }^{\circ}\right.$ Brix $)$ of tomato samples $(7.93 \pm 0.11)^{\circ}$ Brix of old varieties (A1) is higher than those of varieties $(5.00 \pm 0.00$ and
$4.00 \pm 0.00^{\circ}$ Brix) respectively Kilélé and Cobra 26 (Figure 4). The mean values of the three tomato varieties are generally significantly different $(\mathrm{P}<0.05)$ (Figure 4).

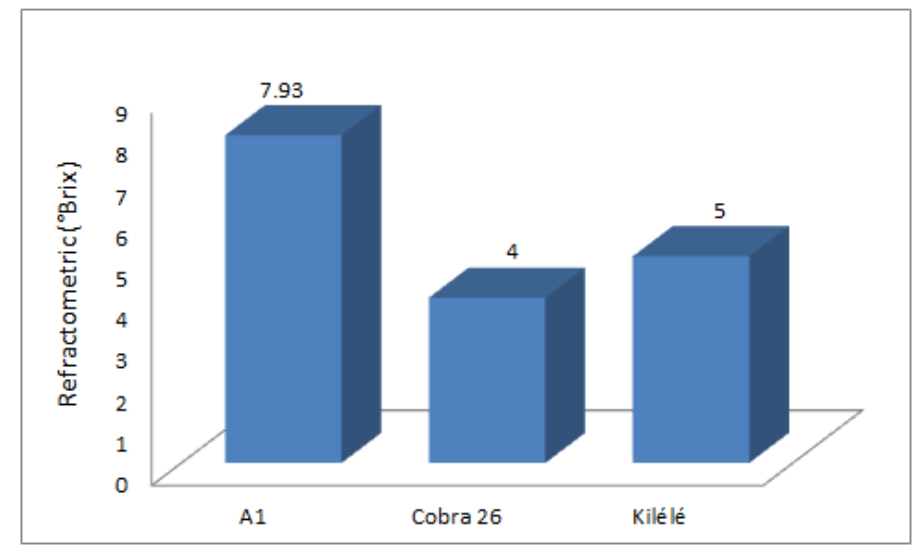

Fig-4: Refractometric solids content $\left({ }^{\circ}\right.$ Brix) of tomato varieties

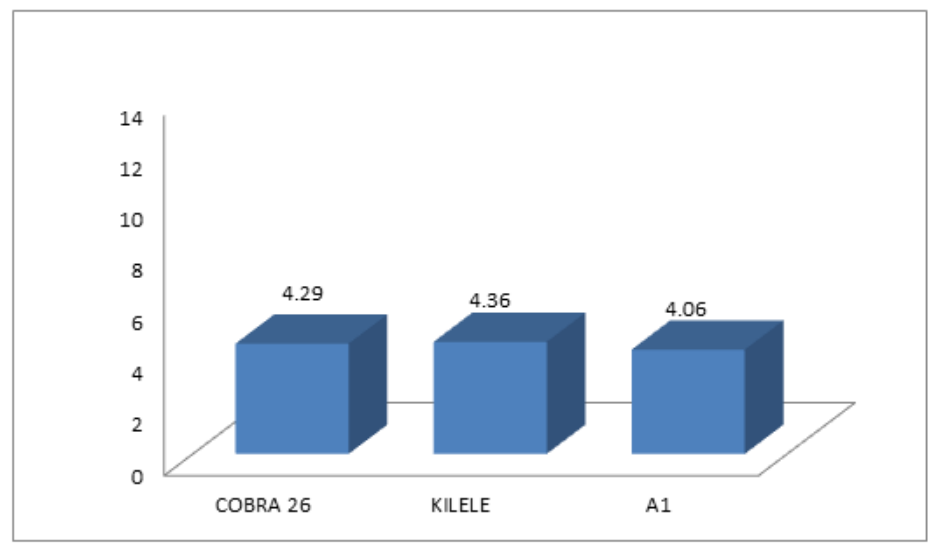

Fig-5: Hydrogen potential (pH) of tomato varieties

The results relating to the $\mathrm{pH}$ of the three varieties of tomato are shown in fig 5 . The analyzes revealed, at a threshold of $5 \%$ that the $\mathrm{pH}$ of all the varieties of tomatoes (old (A1), Kilélé and Cobra 26) are statistically identical.

\section{Acid content of tomato varieties}

The comparison of the means shows a variation in the acidity levels between the tomato varieties, which can be explained by a significant difference at the threshold of 0.05 (Figure 6). The results show that the improved variety (Kilélé) is significantly lower in acidity $(5.12 \pm 0.22$ meq.g / 100g) compared to the old variety (A1) which has a higher acidity rate (9.33 \pm 1.53 meq.g / 100g) (Figure 6). 


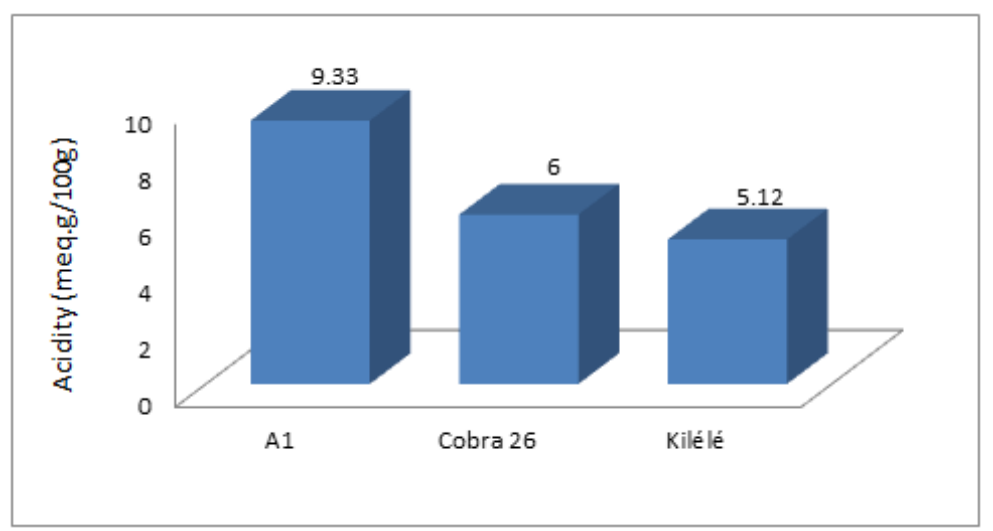

Fig-6: Acidity level of tomato varieties

\section{Vitamin $C$ content of tomato varieties}

The vitamin $C$ level is between $150.29 \pm 7.33$

$\mathrm{mg} / 100 \mathrm{~g}$ (Cobra 26) and 156.16 $\pm 7.33 \mathrm{mg} / 100 \mathrm{~g}(\mathrm{~A} 1$ or Kilélé) (Figure 7). These rates are significantly identical to the $5 \%$ threshold. Cobra 26 is the variety with the lowest amount.

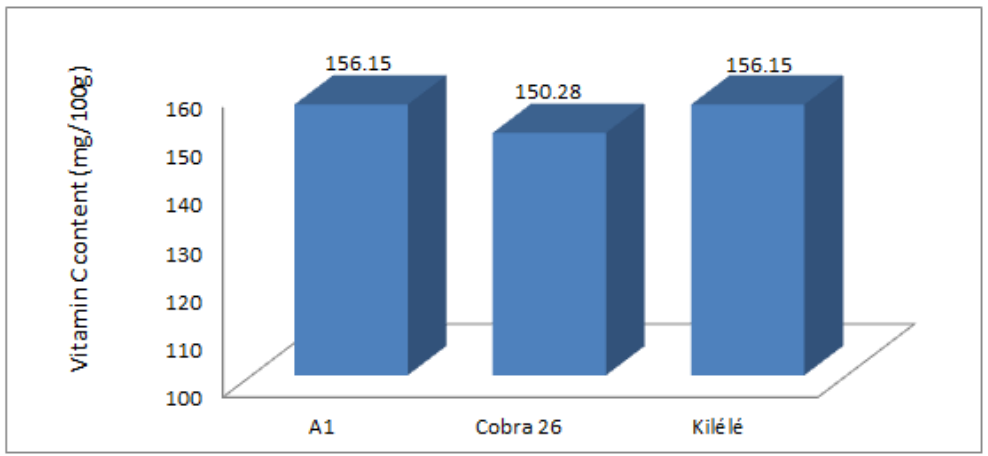

Fig-7: Taux de vitamine $C$ des variétés de tomate

\section{Organoleptic characteristics of tomato varieties Acceptability of tomato varieties}

Table I summarizes the acceptability of the three tomato varieties by the 80 tasters. The judgment made by tasters on the three varieties of tomato from the said locality (Daloa), showed average tomato appreciation scores of $5.05 \pm 1.77$ and $6.21 \pm 1.73$ respectively. These average ratings correspond to the "pleasant" level (note of 6) for improved varieties
(Cobra 26 and Kilélé) and to the level "neither unpleasant nor pleasant" (note of 5) for old varieties (A1) on the 'satisfaction scale. However, no significant difference was observed at the 5\% threshold between the average appreciation scores of improved varieties (Cobra 26 and Kilélé), with the exception of old varieties (A1).

Table-I: Acceptability of the three tomato varieties

\begin{tabular}{|l|l|}
\hline Varieties & Acceptability \\
\hline Cobra 26 & $6.16 \pm 1.83^{\mathrm{a}}$ \\
\hline Kilélé & $6.21 \pm 1.73^{\mathrm{a}}$ \\
\hline A1 & $5.05 \pm 1.77^{\mathrm{b}}$ \\
\hline
\end{tabular}

The values are the mean \pm the standard deviation $(n=3)$. The contents with the different alphabetical letters on the same columns are significantly different $(\mathrm{P}<0.05)$, according to Tukey's test

\section{Sensory profile of the three tomato varieties}

Figures 8, 9 and 10 represent the sensory profile of the three varieties of tomato. The characteristics studied are: color, aroma, flavor and astringency. Analysis of Figure 8 shows that the improved Cobra 26 varieties exhibit a sweet and juicy taste. These varieties are red in color and have a very firm shape. Figure 9 indicates that the improved Kilele varieties are very firm and have a sweeter, crunchier and juicier taste, a red color and a less pronounced aroma. As for figure 10, it reveals that the old varieties (A1) are characterized by a more sour taste and a redder color. 


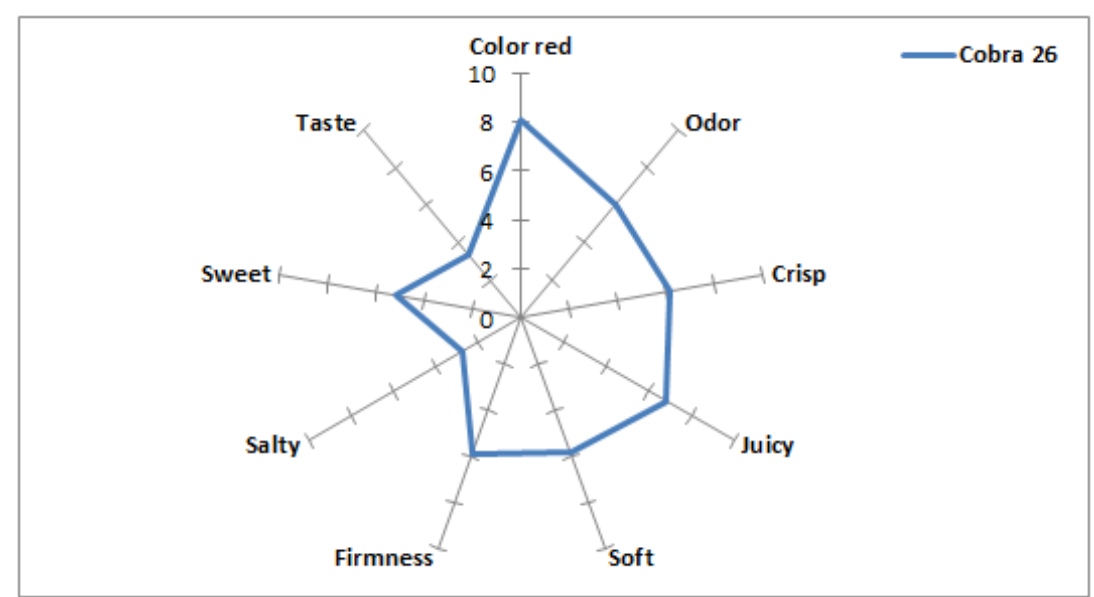

Fig-8: Profil sensoriel des variétés Cobra 26

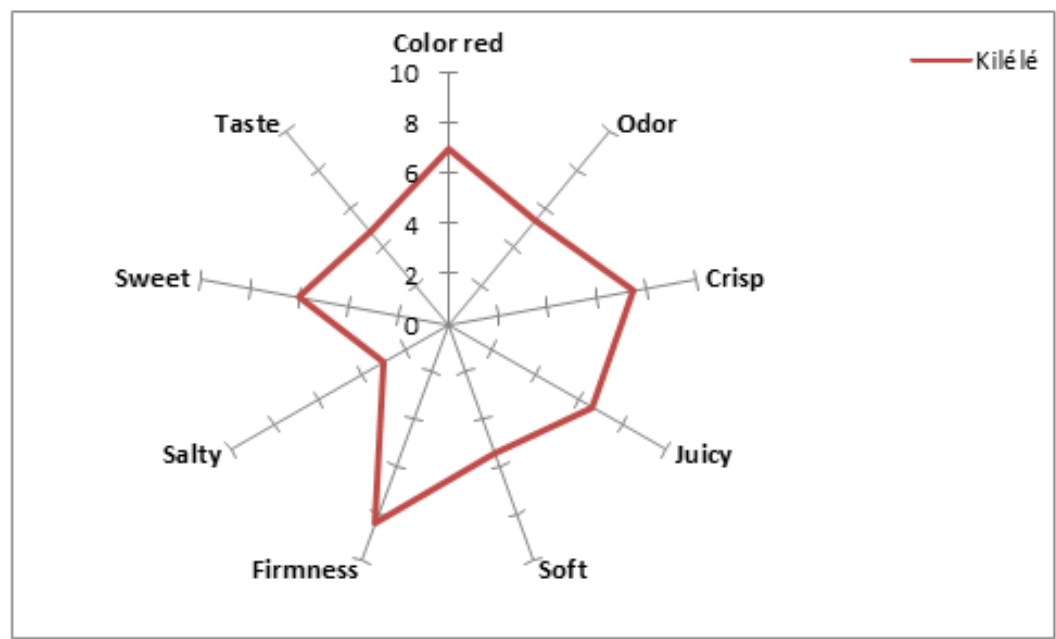

Fig-9: Sensory profile of improved Kilélé varieties

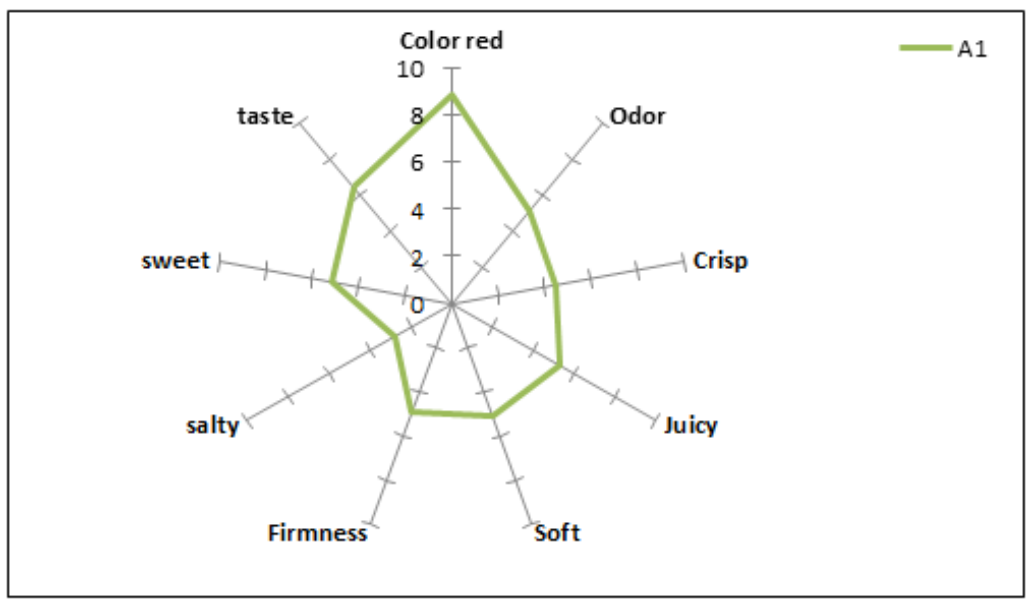

Fig-10: Sensory profile of A1 old varieties

Comparison of sensory profiles of the three tomato varieties

The comparison of the sensory profile of tomato varieties was carried out. The results obtained are shown in Figure 11. On analysis, there are significant differences $(p<0.05)$ between the profiles of the three tomato varieties from the locality of Daloa. 


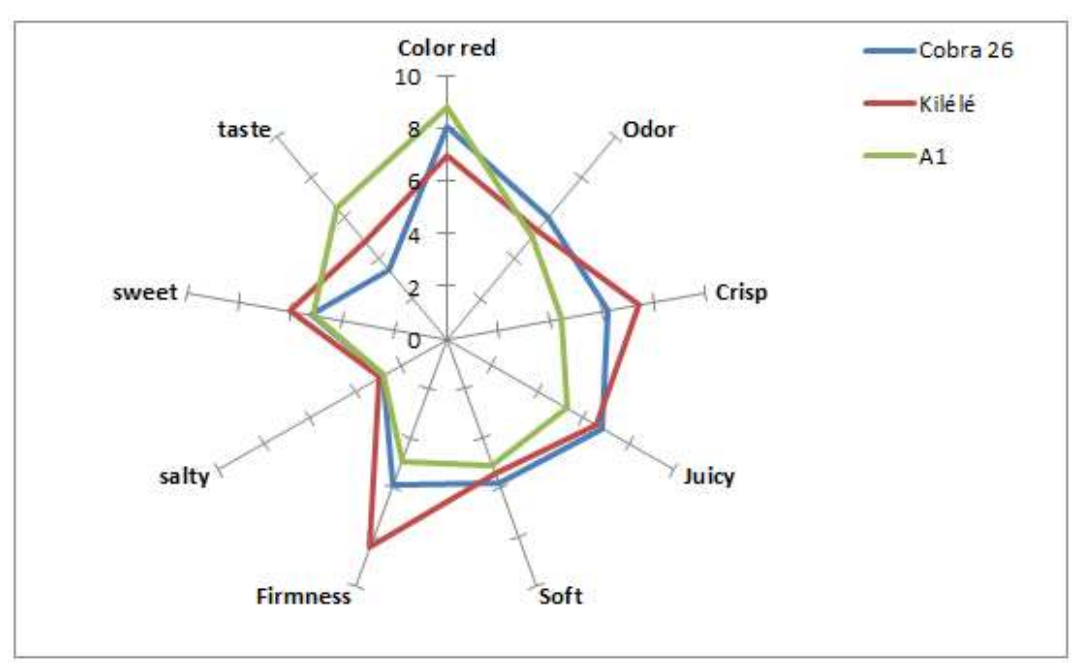

Fig-11: Comparison of sensory profiles of the three tomato varieties

\section{DISCUSSION}

The physicochemical compositions of the three varieties of tomato (A1, Cobra 26 and Kilélé) were determined in order to understand their dietary importance. This study indicated that the three mushroom species analyzed have a water content of between $91.35 \%$ and $94.52 \%$ depending on the fresh weight. In addition, statistical analysis revealed a significant difference $(p<0.05)$ in these contents and clearly showed that the improved varieties have the highest water contents. However, the differences in water content of the tomatoes studied could be partly due to variations in cultivation techniques. Furthermore, the very high water content of tomato fruits is a parameter which would reflect the high perishability of the tomato and limit its aptitude for storage at room temperature [16].

The ash contents of the three varieties of tomatoes are between 10.64 to $13.29 \%$. These rates are higher than those obtained by [17] on tomatoes in Benin which is $0.56 \%$. This high ash content indicates that all three tomato varieties are said to be good sources of minerals. This is because ashes are residues of mineral compounds that persist after incineration of organic substances of animal or plant origin [18].

The $\mathrm{pH}$ of the tomatoes studied varies from 4.06 to 4.36 . These $\mathrm{pH}$ values corroborate with those of [17] working on tomato varieties in Benin. These authors obtained an average value of $\mathrm{pH} 4.36$. The relatively low $\mathrm{pH}$ of tomatoes is an advantage from a product stability point of view. Indeed, this low $\mathrm{pH}$ could considerably reduce the development of microorganisms in fruits [17]. Because the $\mathrm{pH}$ below 4.5 is favorable to the decrease in the proliferation of microorganisms [19].

The $\mathrm{pH}$ of tomatoes varies according to the degree of maturity of the variety [16]. The acidity of the tomato varieties studied indicates that there is a significant difference $(\mathrm{p}<0.05)$ between the acidity contents of the A1 tomato (9.33 meq.g/100g) and those of Cobra 26 tomatoes (6 meq.g / 100g) and Kilélé (5.12 meq.g / 100g). These contents are higher than those reported by [17], by [20] and by [21]. These authors found acidity contents respectively of 4.4 to $5.72 \%$ on tomatoes in Benin, of 0.39 to $0.55 \%$ of citric acid on the Mongol F1 variety in Burkina Faso and of 0.22 at $0.51 \mathrm{~g} / 100 \mathrm{~g}$ of citric acid on traditional tomatoes from Morocco. This difference in acidity content between different varieties of tomatoes could be due to the ripening process of the tomatoes. Indeed, the drop in acid levels (citric and malic) leads to an increase in the sugar content. This difference could be related to genotypes. The degree of brix or the refractive index is an important quality parameter in the acceptability of fruits and vegetables.

In this study, the average values of the refractometric dry extract oscillate between 4.00 and 7.93. There is a significant difference between the values in degree brix of the A1 tomato $\left(7.93^{\circ} \mathrm{Brix}\right)$ and those of the Cobra 26 tomatoes $\left(4^{\circ}\right.$ Brix) and Kilélé $\left(5^{\circ}\right.$ Brix). The values in degree brix of Cobra 26 (4 ${ }^{\circ}$ Brix) and Kilélé ( $5^{\circ}$ Brix) tomatoes are similar to those of [20] which is 4.07 and $5.51^{\circ}$ Brix on tomatoes of the Mongol F1 variety in Burkina Faso and those of [22] which oscillate between 4.1 and 5.8 degree brix. The vitamin $\mathrm{C}$ level of the three varieties of tomato varies from 150.28 to $156.15 \mathrm{mg} / 100 \mathrm{~g}$. These levels are higher than those of [17] and [23] who respectively obtained values of $33.54 \mathrm{mg} / 100 \mathrm{~g}$ on tomatoes in Benin and 3.73 to $4.34 \mathrm{mg} / 100 \mathrm{~g}$ on tomatoes in Nigeria.

These levels indicate that the tomato varieties in the study are good sources of vitamin C. This high vitamin $\mathrm{C}$ content would indicate that the tomato varieties are in the ripening stage. Indeed, an increase in the content of ascorbic acid (vitamin $\mathrm{C}$ ) in fruits would be an indication that the fruit is still in the ripening stage while a decrease indicates a fruit in senescence. The consumption of tomatoes throughout the Ivorian territory and the variability of biochemical compounds 
lead us to study the acceptability and to establish the sensory profile of the tomatoes studied. At the sensory level, tomato varieties are generally accepted overall. However, the Cobra 26 and Kilélé varieties are more popular than the A1 Variety. This difference in appreciation could be related to variety. Indeed, the variety (A1) is an heirloom tomato and the Cobra 26 and Kilélé tomatoes are improved varieties (hybrid). This difference could also be due to the taste which would be a very important aspect of quality, which would determine the acceptability or the rejection of tomatoes with the consumers. This difference can be seen at the level of sensory profiles. Indeed the old variety (A1) is redder; sourer it is fewer firms, less juicy and less mellow. As for the improved variety (Kilélé), it has a less red color than the others; it is crunchier, firmer and sweeter. The improved Cobra 26 variety is smoother and less sour than the others. It is redder than the improved variety (Kilélé) and juicier, softer and firmer than the A1 tomato. These results could explain the difference in acceptability of tomato varieties. It has been well established by a few researchers that sensory attributes lead to consumer acceptance of foods [24, 25].

\section{CONCLUSION}

The evaluation of the physico-chemical nature of three varieties of tomato (A1, Kilélé and Cobra 26) showed a significant difference. The old variety (A1) exhibited the highest refractometric solids, acidity, ash and vitamin $\mathrm{C}$ contents. Also, the study of the organoleptic quality of the tomato fruits of the said varieties revealed that the tasters perceived sensory differences between the varieties. Among other things, the old variety (A1) is the least appreciated in organoleptic evaluation compared to hybrid varieties (Kilélé and Cobra 26).

\section{REFERENCES}

1. Djioua, T., Charles, F., Murillo, F. J., Filgueiras, H., Freire, J. M., Ducamp-Collin, M. N., \& Sallanon, H. (2010). Combined effects of postharvest heat treatment and chitosan coating on quality of fresh-cut mangoes. International Journal of Food Science and Technology, 45, 849-855

2. Abidi, L., Snoussi, S. A., \& Bradea, M. S. (2017). Variation du taux de brix sous l'effet d'un biofertilisant. U.P.B. Scientific Bulletin, 79(1): 136144.

3. Dao, D., Kouakou, A., Cissé, G., \& Girardin, O. (2003). Programme des Cultures Vivrières Intensives. Rapport d'activités de la phase pilote du PCVI, Abidjan, Côte d'Ivoire, 76.

4. Soro, S., Doumbia, M., Dao, D., Tschannen, A., \& Girardin, O. (2007). Performance de six cultivars de tomates Lycopersicon esculentum Mill. contre la jaunisse en cuillère des feuilles, le flétrissement bactérien et les nématodes à galles. Science et nature, 4(2):123-130.
5. Gerszberg, A., Katarzyna, H-K., Kowalczyk, T., \& Andrzej, K. K. (2014). Tomato (Solanum lycopersicum L.) in the service of biotechnology. Plant Cell, Tissue and Organ Culture, 120: 881902.

6. Sangaré, A., Koffi, E., Akamou, F., \& Fall, C.A. (2009). Etat des ressources phythogénétiques pour l'alimentation et l'agriculture: Second rapport national. Ministère de l'Agriculture de la Côte d'Ivoire. Note d'information de la FAO, 63.

7. BIPEA. (1976). Recueil des méthodes d'analyse des communautés européennes. Bureau Interprofessionnel d'Études Analytiques, Gennevilliers, France, 140.

8. AOAC. (1990). Official methods of analysis. Association of Official Analytical Chemists Ed., Washington DC. 684.

9. JORA $\mathrm{n}^{\circ} 77$. Arrêté interministériel du 24 août 1997 relatif aux conserves de purée de tomate, Journal Officiel de la République Algérienne: 26.

10. Dufour, D., Larsonneur, S., Alarçon, F., Brabet, C., \& Chuzel G. (1996). Improving the bread making potential of cassava sour starch. Cali CIAT, 4: 133142.

11. Board, B. (1987). Le contrôle de la qualité dans l'industrie du traitement des fruits et légumes. Étude F.A.O., Alimentation et Nutrition, $\mathrm{n}^{\circ} 39$, Rome, Italie, 75.

12. Elgamouz, S. (2016). Le suivi de la teneur de la vitamine $\mathrm{C}$ dans un jus industriel. Mémoire de Master Sciences et Techniques, Université Sidi Mohammed Ben Abdellah (Maroc), 54.

13. Publishers B. (2007). Ressources végétales de l'Afrique tropicale. Légumes. Ed. Dunod, tome2 : $736 \mathrm{p}$.

14. Meilgaard, M C., Civille, G. V., \& Carr B. T. (1999). Sensory Evaluation Techniques. $3^{\text {rd }}$ édition CRC Press.LLC, Boca Raton, Florida, New York, USA, 387.

15. Stone, H., \& Sidel, J.L. (1993). Sensory evaluation practices. $2^{\text {nd }}$ edition, Academic Press, In., San Diego, California, USA 338.

16. Dossou J, Soulé, I., \& Montcho M. (2007). Évaluations des caractéristiques physicochimiques et sensorielles de la purée de tomate locale produite à petite échelle au Bénin. Tropicultura, 25(2): 119125.

17. Agassounon, D., Gomez, S., Tchobo, P., Soumanou, M., \& Toukourou, F. (2012). Essai de conservation de la tomate par la technique de la déshydratation imprégnation par immersion (DII). International Journal of Biological and Chemical Sciences, 6(2): 657-669.

18. Audigié, C.L., \& Zanzain, F. (1977). Manipulation d'analyses biochimiques. Doin édition, Paris, $274 \mathrm{p}$.

19. Stevens, M. A. (1972). Citrate and malate concentrations in tomato fruits: genetic control and maturational effects. J. Am. Soc. Hortic. Sci. 97:655-658. 
20. Oboulbiga, E. B., Parkouda, C., SawadogoLingani, H., Compaoré, E.W.R., Sakira, A.K., \& Traoré A.S. (2017). Nutritional Composition, Physical Characteristics and Sanitary Quality of the Tomato Variety Mongol F1 from Burkina Faso. Food and Nutrition Sciences, 8: 444-455

21. Amraoui, R., Addi, M., Mingeot, D., Elamrani, A., Serghini, C. H., Mihamou, A., \& Abid, M. (2018). Morphological, molecular, and physic-chemical characterization of traditional Moroccan tomato (Solanum Lycopersicum L.) genotypes. Journal of Biotech Research 9:58-69

22. Tigist, M., Workneh, T. S., \& Kebede, W. K. (2013). Effects of variety on the quality of tomato stored under ambient conditions $J$ Food Sci Technol, 50(3):477-486.
23. Mohammed, S. M., Abdurrahman, A. A., \& Attahiru, M. (2017). Proximate Analysis and Total Lycopene Content of Some Tomato Cultivars Obtained from Kano State, Nigeria. ChemSearch Journal, 8(1): $64-69$.

24. Lee, J. (2009). Green tea: Flavor characteristics of a wide range of teas including brewing, processing, and storage variations and consumer acceptance of teas in three countries. An abstract of dissertation. Kansas States University, Manhattan, USA. 262.

25. Vittayaporn, V., Chompreeda, P., Haruthaithanasan, V., \& Hathairat, R. (2010). Preference mapping of Thai consumers for commercial green tea with roasted brown rice.Nat. Sci, 44: 652-663.

Cite This Article: Ekissi Alice Christine et al (2021). Physicochemical and Sensory Evaluation of Tomato Varieties (Lycopersicum Esculentum Mill) From the Haut-Sassandra Region (Daloa) Côte d'Ivoire. EAS J Nutr Food Sci, 3(2), 3241. 